\title{
EXPERIMENTELLE EINFÜHRUNG
}

\author{
IN DIE
}

\section{UNORGANISCHE CHEMIE}

\author{
VON
}

\section{HEINRICH BILTZ}

MIT FUUNFZEHN FIGUREN

\author{
VIER'TE AUFI,AGE
}

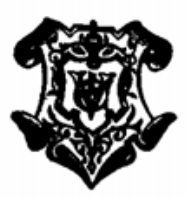

LEIPZIG

VERLAG VON VEIT \& COMP. 
Der Verfasser behält sich das Recht der Übersetzung vor. 